\title{
Assessing the Implementation of Fieldwork in the Teaching of Geography in Some Senior Secondary Schools in Kano, Nigeria
}

\author{
Nuratu Mohammed \\ Department Of Geography, Faculty of Earth and Environmental Sciences, Bayero University, P.M.B, 3011, \\ Kano, Nigeria
}

\begin{abstract}
Geographical field work has been argued to be particularly useful in the development of insight, attainment of cognitive/intellectual, technical achievements and development of empathy in students. In view of this argument therefore geographical field work becomes an inalienable and corporate part of teaching and learning process in schools. The study therefore assesses the implementation of fieldwork in some senior secondary schools in Kano state. Stratified random sampling was used to select 10 schools out of the 34 public senior secondary in the metropolitan area. Teachers' and students formed the sampling frame for the study. All the geography teachers in the selected schools were use as samples since their number is not large. This way a total of 37 geography teachers were selected for the study. Stratified random sampling was employed to select 50 students from six schools out of the ten sampled schools. Data was gotten through the participant observation and administration of questionnaire to the samples. The students were pre tested on some selected concepts in physical geography before going to the field. The pre and the post fieldwork tests were analysed using mean, standard deviation and analysis of variance. The result show significant difference in the mean scores of students for the pre and post test scores. The study found among other things, that the field work was better in enhancing students understanding of geographical concepts and appreciation of the natural environment; it was also found that the involvement of students in group work was seen as a step in the development of leadership roles amongst them. Some of the major constraints to the effective implementation of field work in schools are attributed to inadequate preparation on the parts of the teachers, large classes, time constraint and inadequate funding insecurity amongst others.
\end{abstract}

Key words: Field work, Gender, and Geography

\section{INTRODUCTION}

According Biggs et al (1999) the concept of field work is seen to be the "active engagement with the external world" whether every activity described as fieldwork fits the criteria of "active engagement" is debatable. Ajibade and Raheem (1999) Defined "fieldwork" to include field teaching, field trips, field research or field camps or indeed "any arena or zone within a subject where, outside the constraints of the four walls classroom setting, supervised learning can take place via firsthand experience" According to Gold and Jenkins( 1991) field work may be categorise into five types of activity: Short field excursion: limited travel in limited time; Cook's Tour: limited activity in extended travel ;Residential course: extended travel and time ; Study tour: multi location activity, Project work: (i) learner-practitioner and (ii) participant observation.

No matter whichever form it may take, Geographers have long regarded fieldwork as being central to their teaching, research, and as something intrinsic to the very nature of being a geographer. Gold and Jenkins (Fletcher et al 2003) argue that fieldwork is as rooted to the Subject Geography as clinical practice is to medicine. Teaching of Geography without fieldwork feigns the interaction of person and the environment.

Geography as a secondary school subject aims at helping learners understand their immediate environment as well as that of the universe (Akintade, 2012) this cannot happen in rigidly planned classroom activities where the teacher and the textbook are the only source of information. For Learners to be able to give some explanations on what they see on the landscape they need to have direct contact with this landscape and the only way of achieving this aim is by taking learners out of the walls of the classroom to the place where they will experience a direct contact with the landscape. By so doing, learners will learn by doing and by observing. This is what chemistry students do in their laboratories and the laboratory for Geography lessons is on the field (Rogers et.al 1994; Barnett, 2009; Young et al, 2010).

However in some quarters geographic field work tended to be confused with picnics outings or class excursions this should be seen as a narrow concept of the term field work. For success and attainment of the goals of field work, Barnett (2009) opined that the following stages are critical : Abstract conceptualisation (pre field activities in class teaching and learning), Active experimentation (planning for Fieldwork) Concrete experience (conduct of the field work), and Reflective observation (post fieldwork evaluation) 
Indeed many schools do undertake field trips that are normally called "trips of the year". These trips usually take place towards the end of the academic year when normal classroom sessions have ceased and learners are only waiting to write examinations or after their examinations. In this type of trips, for most part the stages for successful implementation of field work are not observed thus there are no goals stated for such trips, no purpose given and no follow-up is made. Failure to use these outings productively leads to shallowness in the learners' understanding and in their perception of the spatial phenomena. They are" told" about the nature and denied the real experience. (Fletcher et al 2003) This type of trips of the year is what takes place in most schools in Nigeria in general and the study area in particular. The need therefore to assess the effective implementation of fieldwork as one of the methods used in teaching geography in secondary schools.

\section{RESEARCH QUESTIONS}

In this study the following question will direct the research work: How qualified are Geography teachers to conduct fieldwork? How much teaching experience do secondary school Geography teachers have? How much importance or value do schools attach to fieldwork? What level of preparation is made by Geography teachers when undertaking fieldwork? What are the constraints to the proper implementation of fieldwork in Geography? The main objectives of this study are as follows: Describe the personal characteristics of the teachers; to investigate the teachers' level of preparation for field work, examine the potential importance of fieldwork in geography and the benefits to students; to examine the constraints of fieldwork implementation in secondary schools.

\section{STUDY AREA}

The study was carried out in Kano state .Kano state lies within latitude $10^{0} 30^{\prime} \mathrm{N}$ to $12^{0} 30^{\prime}$ and $7^{0} 30^{\prime}$ to $9^{0} 25^{\prime} \mathrm{E}$ It is bordered in the north and east by Jigawa state in the west by Katsina and Kaduna states and in the south by Kaduna and Bauchi states. Specifically however the study was conducted in Nassarawa education zone is found within the Kano metropolitan area. The

The state, Kano lies within the Sudan Savannah belt, with the Guinea Savannah bordering in the south. The climate of the area is Tropical wet and dry climate, coded Aw by Koppen's Climatic Classification System. Mean monthly temperatures range from $21^{\circ} \mathrm{c}$ in the coolest months to over $31^{\circ} \mathrm{c}$ in the hottest months. The average rainfall in a normal year is about $1000 \mathrm{~mm}$ in the southern part of the state (Olofin, 1987).The Kano Chronicle asserted that the city was founded in the $9^{\text {th }}$ century CE around the Dala Hill (Olofin, 1987 ,Dankani,2013).The strategic location of Kano along the Tran Saharan trade route made Kano city to become centre of commerce since the $15^{\mathrm{TH}}$ century. According to Dankani (2013) the spatial planning and development of Kano started with the building of the first city wall between 1095 and 1134.After independence Kano witnessed an unprecedented urbanization and population growth in its socio economic transformation. Thus by the time the colonial masters came in the early $20^{\text {th }}$ Century, what constitute Kano had been virtually encompassed by walls and was within $17.5 \mathrm{~km}^{2}$. Today metropolitan Kano is contained within the radius of $60 \mathrm{~km}^{2}$. Hausa and Fulani ethnic group is the predominant tribe in the state. However other minority tribes /ethnic groups also found in the state are the Yoruba and Ibo (accounting for the large segment of nonindigenous population), Tiv, Nupe Idoma, Igala and a host of others. Islam is the dominant religion. There has been increase in the expansion of the educational sector with the demand for education to commensurate with the increasing population of Metropolitan Kano including the study area. Thus As far as education is concerned (Figure 1) there over 72 registered public senior secondary and over 50 registered private schools in the Nassarawa educational zone . 


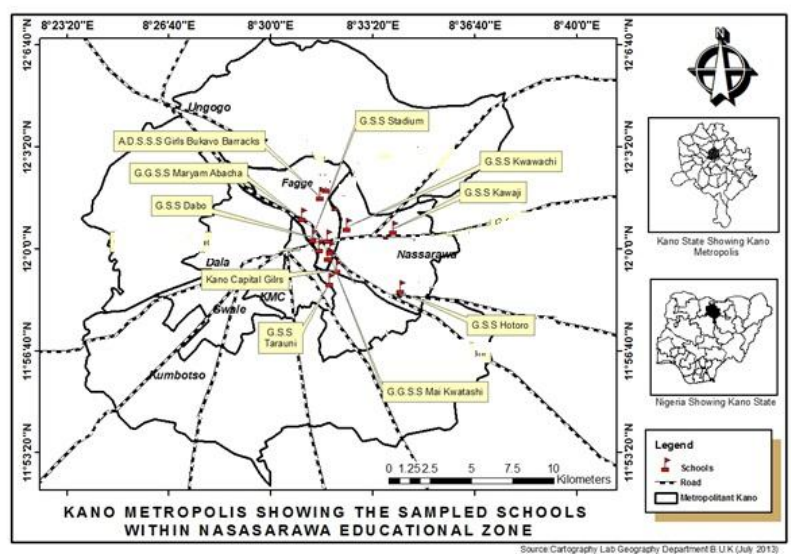

Figure 1 Kano Metropolitan showing the study areas.

IV. MATERIALS AND METHODS

The lists of schools in Nassarawa education zone was gotten from the office of the director senior secondary schools Management board. Data was gotten through the administration of questionnaire and participant observation method. A total of 37 copies of questionnaire was administered to 37 teachers selected as samples across 10 schools while 300 copies of the second set of questionnaire was administered to 300 students from 6 out of the 10 sampled schools.List of the sampled schools is given below:
1) G.S.S .Stadium 2, G.S.S Kwakwachi
3) A.D.S.S.S Girls, Bukavu
4) G.S.S.Kawaji
5) G.S.S Dabo
6) G.G.S.S Maryam Abacha 7) G.S. S.Tarauni
8) G.S.S Maikwatashi
9) G.S.S Hotoro
10) Kano Capital Boys

\section{DATA ANALYSIS}

Data was analyzed using descriptive statistics and analysis of variance.

\section{RESULTS AND DISCUSSION}

The results of the study is presented in tables and discussed below:

Table 1 shows the qualification and gender of the teachers. The inference drawn from the table is that majority of geography teachers in the schools sampled are males approximately $28(76 \%)$ are males while only $9(24 \%)$ are females. This is a reflection of gender dichotomy in subjects offered in schools amongst males and females which also extend to areas of specialization. Socio cultural factor have been found to be influential in the subject specialization and consequently career of males and females in the study area. This confirmed Fafunwa's (1997) findings who opined that social, cultural and ideological process have been influential in discrimination in educational process of males and females in terms of the kind of education e.g. domestic science and nursing for girls and Medicine and Engineering for boys.

Education wise majority of the respondents (54\%) have the Nigerian Certificate of Education (NCE) as their educational qualification. A slightly higher number than one quarter of the respondents have first degree as their highest qualification.

Table 1: Educational Level/Qualification and Gender of Respondents

\begin{tabular}{|l|l|l|l|l|l|l|}
\hline Qualification & \multicolumn{4}{|c|}{ Gender } & \multicolumn{2}{l|}{ Total } \\
& Males & \multicolumn{2}{|c|}{ Females \% } & \multicolumn{2}{c|}{ \% } \\
\hline NCE & 16 & 43 & 4 & 10.8 & 20 & 54 \\
\hline Degree & 8 & 22 & 3 & 8 & 11 & 29 \\
\hline Masters & 1 & 2.7 & 1 & 2.7 & 2 & 5.4 \\
\hline Others & 3 & 8 & 1 & 3 & 4 & 11 \\
\hline Total & 28 & 75 & 9 & 25 & 37 & 100 \\
\hline
\end{tabular}

Source: Field work, 2015 
Teacher's area of specialization is of potential influence in their interest and attitude to field work. The inference drawn from the findings on table 2 show that less than one fifth (19\%) of the respondents studied science based courses as their specialization and (22\%) of the teachers did other courses other than geography and only teach geography because they were employed to do that by their employers. More than half of the teachers (59\%) studied geography. This implies that they possess the basic knowledge for teaching the course and are expected to have what Lambert (2013) described as powerful knowledge which enables teachers to extend and deepen their thinking beyond their every day experiences. Thus teacher's knowledge and academic competence in their field or area of specialization vis a vis methods of teaching, ability to reflect on geographical issues play important role in the success of field work among other things (Mayring 2010; Fletcher, 2003).

Table 2: Teacher's Subject Specialization

\begin{tabular}{|c|c|c|c|c|c|c|}
\hline \multirow[t]{2}{*}{ Specialization } & \multicolumn{3}{|c|}{ Gender } & \multirow[b]{2}{*}{$\%$} & \multicolumn{2}{|c|}{ Total } \\
\hline & Males & $\%$ & Females & & & $\%$ \\
\hline $\begin{array}{l}\text { Geography and other } \\
\text { social Science course }\end{array}$ & 16 & 43 & 6 & 16 & 22 & 59 \\
\hline $\begin{array}{l}\text { Biology/Other Science } \\
\text { courses like math }\end{array}$ & 4 & 11 & 3 & 8 & 7 & 19 \\
\hline $\begin{array}{l}\text { Course not related to } \\
\text { Geography }\end{array}$ & 8 & 22 & 0 & 0 & 8 & 22 \\
\hline Total & 28 & 76 & 9 & 24 & 37 & 100 \\
\hline
\end{tabular}

Source: Field work, 2015

It has been observed that the success of any field work is premised on the quality of the field activities that students are involved in during the pre field, (which is expected to pre test students prior knowledge/concepts on the topic of field work), the actually outing on the field where students are expected(to observe, perceive, think, analyse, synthesise, record, inquire, compute, classify etc) and the post field where the students are expected to present their work through application, synthesis, reflections on all the field activities (Lambert ,2013). The success of all the stages reflects the teacher's level of preparation for the field work. As a participant observer, the activities assigned to the students at each stage of the field work was scored based on the criteria adopted from Barnett (2009) and Lambert (2013). The result show that all the schools (100\%) did engaged in pre field and but as for the post field activities all the schools sampled as observed were rated on average as below 50 percent. This is contrary to the opinion of Bain etal (1999) who opined that reflection on geographical issues and processes is an essential part of geographical thinking and inquiry which should be the main focus of field work.

Table 3: Stages in the Implementation of Field work

\begin{tabular}{|l|}
\hline Stages of Field work \\
\hline Pre Field Activities (Abstracts Conceptualisation stage) \\
\hline Field Activities (Active Experimentation/Concrete Experience) \\
\hline Post field Activities (Reflective thinking). \\
\hline
\end{tabular}

Source: Adapted from Barnett, 2009

The interview held with the teachers on the frequency of fieldwork shows that majority (80\%) of the schools carry out field work once a year, while less than one quarter (20\%) go for field work on twice in a year and non of the schools was found to go for field work on a quarterly basis. This confirmed the findings of Fletcher (2003); Rogers (1999) who were of the view that many schools do undertake field trips that are normally called "trips of the year". These trips described by Rogers (1999) as Excursion, usually take place towards the end of the academic year when normal classroom sessions have ceased and learners are only waiting to write examinations or after their examinations and which only take between one to two days.

\section{ASSESSING THE IMPACT OF FIELD WORK ON} STUDENT'S PERFORMANCE

From the analysis of the data shown in table 2 it shows that there is no significant difference between the pre test scores of pre test given to six schools sampled as indicated in table 4 since the F critical was more than the $\mathrm{F}$ calculated 1 at 0.05 level of significance. 


\begin{tabular}{|l|l|l|l|l|l|l|}
\hline \multicolumn{2}{|l|}{ Table 4 :Pre test Scores } & & & & & \\
\hline Groups & Count & Sum & Average & Variance & & \\
\hline Sch2 & 2 & 1079 & 539.5 & 169944.5 & & \\
\hline Sch4 & 2 & 1124 & 562 & 189728 & & \\
\hline Sch5 & 2 & 1171 & 585.5 & 251340.5 & & \\
\hline Sch6 & 2 & 1233 & 616.5 & 285012.5 & & \\
\hline Sch8 & 2 & 1176 & 588 & 269378 & & \\
\hline Sch10 & 2 & 1176 & 588 & 235298 & & \\
\hline & & & & & & \\
\hline ANOVA of & SS & Df & MS & F & P-value & F crit \\
\hline $\begin{array}{l}\text { Source } \\
\text { Variation }\end{array}$ & 6909.417 & 5 & 1381.883 & 0.005919 & 0.999987 & 4.387374 \\
\hline $\begin{array}{l}\text { Between } \\
\text { Groups }\end{array}$ & 1400702 & 6 & 233450.3 & & & \\
\hline Within Groups & & & & & & \\
\hline & 1407611 & 11 & & & & \\
\hline Total & & & & & & \\
\hline
\end{tabular}

At the end of the field outing students were tested with a view to finding out the effectiveness of field trip on the geographical concepts taught. It was found that the mean scores of students in the six schools show significant difference between the pre test and post test scores of students since the calculated ' $F$ ' ratio was greater than the table value.

\begin{tabular}{|c|c|c|c|c|c|c|}
\hline \multicolumn{2}{|c|}{ Table 5:Pre and Post test } & & & & \\
\hline Groups & Count & Sum & Average & Variance & & \\
\hline Pre test & 6 & 1438 & 239.6667 & 145.4667 & & \\
\hline Post test & 6 & 5521 & 920.1667 & 3528.567 & & \\
\hline ANOVA & & & & & & \\
\hline $\begin{array}{c}\text { Source of } \\
\text { Variation }\end{array}$ & $S S$ & $D f$ & MS & $F$ & P-value & F crit \\
\hline Between Groups & 1389241 & 1 & 1389241 & 756.2483 & $9.37 \mathrm{E}-11$ & 4.964603 \\
\hline Within Groups & 18370.17 & 10 & 1837.017 & & & \\
\hline Total & 1407611 & 11 & & & & \\
\hline
\end{tabular}

The students were asked of their field experiences vis a vis what they benefitted their response is given in table 6.The inference drawn from table 6 is that a slightly lower than a half (50\%) number of students in all the schools said they acquired first hand information

Table 6: Benefits student's derived from Fieldwork

\begin{tabular}{|c|c|c|c|c|c|c|c|c|c|c|c|c|}
\hline \multirow{3}{*}{$\begin{array}{l}\text { Benefits derived } \\
\text { Acquired first } \\
\text { hand } \\
\text { information }\end{array}$} & \multicolumn{12}{|c|}{ SAMPLED SCHOOLS } \\
\hline & \multicolumn{2}{|c|}{ Kwakwachi } & \multicolumn{2}{|c|}{ Kawaji } & \multicolumn{2}{|c|}{ Dabo } & \multicolumn{2}{|c|}{$\begin{array}{l}\text { Maryam } \\
\text { A }\end{array}$} & \multicolumn{2}{|c|}{ Maikwatashi } & \multicolumn{2}{|c|}{ Capital } \\
\hline & 20 & 40 & 15 & 30 & 15 & 30 & 10 & 20 & 18 & 36 & 15 & 30 \\
\hline Enjoyed Self & 15 & 30 & 10 & 20 & 10 & 20 & 10 & 20 & 10 & 20 & 10 & 20 \\
\hline $\begin{array}{l}\text { Leadership/team } \\
\text { spirits Skills }\end{array}$ & 5 & 10 & 5 & 10 & 5 & 10 & 10 & 20 & 5 & 10 & 5 & 10 \\
\hline $\begin{array}{l}\text { Relates with } \\
\text { teachers better }\end{array}$ & 5 & 10 & 5 & 10 & 5 & 10 & 10 & 20 & 5 & 10 & 5 & 10 \\
\hline All the above & 5 & 10 & 15 & 30 & 15 & 30 & 10 & 20 & 12 & 24 & 15 & 30 \\
\hline Total & 50 & 100 & 50 & 100 & 50 & 100 & 50 & 100 & 50 & 100 & 50 & 100 \\
\hline
\end{tabular}

\section{Source Field work, 2015}

2) G.S.S .Stadium 2, G.S.S Kwakwachi 3) A.D.S.S.S Girls,Bukavu
4) G.S.S.Kawaji
5) G.S.S Dabo
6) G.G.S.S Maryam Abacha 7) G.S. S.Tarauni
8) G.S.S Maikwatashi
9) G.S.S Hotoro
10) Kano Capital Boys 


\section{TEACHER'S PERSPECTIVES ON BENEFITS DERIVED} FROM FIELD WORK.

The inference drawn from the result shown in table 7 is that approximately one third of the respondents $(32 \%)$ were of the view that field work has the potential of improving the cognition/understanding of concepts through improved perception, classification application, description analysis and synthesis .In addition to improved cognition approximately one third of the teachers $(30 \%)$ opined that Field work can also improve students psycho motor domain via the use geographical instruments to monitor, manipulate and model certain geographical features. However this aspect of field work had a lower scored than other variables because of the reluctance of teachers in most schools to provide students with task that demands them to make use of their psycho motor domain. As for attitude change or affective domain a little above a quarter (30\%) of the teachers observed that those students who went for the field work came back happy and made new friends and felt more relevant through cooperation they had with other members of the group. This confirmed the findings of Fletcher et al (2003) who affirmed that the affective attitude (enjoyment), value (importance) and interest were "significantly enhanced" in students by local (on-site) field activities. Students who engaged in fieldwork left the course feeling much higher levels of importance, interest and enjoyment.

Table: 7: Teacher's perspectives on the benefits of field work

\begin{tabular}{|l|l|l|l|l|l|l|}
\hline BENEFITS & \multicolumn{2}{l}{ Male teachers-=28 } & \multicolumn{3}{l|}{ Female teachers N=9 } \\
\hline Cognitive & 10 & 27 & & 2 & 5 & 32 \\
\hline Psychomotor & 8 & 21 & & 3 & 8 & 30 \\
\hline Affective & 2 & 5 & & 1 & 3 & 8 \\
\hline All of the above & 8 & 21 & & 3 & 8 & 30 \\
\hline Total & 28 & 74 & & 9 & 26 & 100 \\
\hline
\end{tabular}

SOURCE: Field work, 2015

Despite the benefits of field work given in table 7 much is still yet to be expected as far as the use of field work as a method of teaching in senior secondary schools is concerned. According to the teachers' the use of fieldwork as a method of teaching geography is constraint by a number challenges given in table 8 .

The results in table 8 show that almost a quarter of the teachers opined that time was one of the challenges confronting the use of field work as a method of teaching in schools, inadequate funding where a little over one quarter $(27 \%)$ of the teachers contended to. It has been observed that all the stages of field work is hinged on fund available for the programme in the absence of students may be asked to make contribution for the conduct of the field work. Students' population in most secondary schools have been on the increase as a result of modernization and the recognition of the importance of education as a result it is usually the norm to find over 80 students in a class in public schools which is also as a stress on available infrastructures and security issues. (Field work, 2015).Other factors that have constrained field work in schools are time allocation to geography. Approximately $15 \%$ opined that was not adequate for the field work. The researcher observed that the time allotted to geography in most schools never exceed four periods of 40 minutes by week per stream/class given the vast content of geography this time is inadequate.

The security issues in Nigeria today has also contributed to the problem of using field work as a method of teaching geography in secondary schools in the study areas. Approximately $12 \%$ of the respondents were of the view that security issues in the study area call for concern and has affected the rate at which field work is being carried out in schools.

Teacher's qualification is the basis for the success of any education programme. The responses of the teachers on this issue is given in table 7 where approximately $15 \%$ were of the view that inadequate experience has implication for planning successful field work. Thus the success of fieldwork can be attributed to the teachers powerful knowledge, (Lambert 2013) described as knowledge which transcends every day knowledge.

Table 8: Constraint to the use of field work in Geography

\begin{tabular}{|l|l|l|}
\hline Constraint & $\mathbf{N}=\mathbf{3 7}$ & \% \\
\hline Funding & 9 & 27 \\
\hline Time & 17 & 15 \\
\hline Inadequate infrastructures & 4 & 19 \\
\hline Security issues & 3 & 11.5 \\
\hline $\begin{array}{l}\text { Teacher's } \\
\text { qualification/Experience }\end{array}$ & 4 & 15 \\
\hline Total & 37 & 100 \\
\hline
\end{tabular}




\section{Source: Field work, 2015.}

\section{CONCLUSION.}

The conclusion drawn from the study points to the fact that field work if properly planned and executed has the power to increase students understanding and appreciation of $\%$

[1] Ajibade,L.T. And Raheem,U.A 1999. Re-appraissal of field work as a teaching method in geography in Ilorin Journal of Education.Ilorin:Haytee

[2] Akintade, B.O (2012) Considering the determinants of selecting geography as a discipline: The case of senior secondary school students in Ilorin in Ozean Journal of Social sciences 5 (1)

[3] Adeyemi, M.B. (2010). Factors Influencing the Choice of Geography as an Optional Subject: A Case of a Senior Secondary School in Botswana. Journal of Social Science, 20 (2): 101-104

[4] Bain, J.D., Ballantyne,R.\& Packer, J (1999) : Using Journal Writing to Enhance StudentTeachers'Reflectivity During Field Experience Placements. Teachers and Teaching: Theory and Practice

[5] Barnett, R (2009) Knowing and becoming in higher Education Curriculum. Studies in Higher education, 34(4):429-440

[6] Biggs J. (1999) Teaching For Quality Learning at University, SRHE/OU, Buckingham.

[7] Dankani, I.M (2013) Constraints to Sustainable Physical Planning in Metropolitan Kano. International Journal of Management and Social Sciences Research ( IJMSSR)

[8] Fafunwa, A.B. (1997): History of Education in Nigeria. Sydney: George Allen and Unwin.

[9] Federal Republic of Nigeria (2006) National Population Commission.

[10] Fletcher, S., France, D., Moore, K., \& Robinson, G. (2003) Fieldwork, Education and Technology: A GEES perspective, Planet, 4, pp.17-19.

[11] Haigh, M.\& Gold ,J.R (1993) The problems with fieldwork: a group based approach towards integrating fieldwork into the undergraduate geography curriculum, Journal of Geography in Higher Education, 17, pp. 21-32.Lambert, D (2013) Reviewing the case for geography and the 'knowledge turn' in the English national curriculum, The Curriculum Journal, 22, 3, pp 243-264

[12] Lambert, D \& Morgan, J (2010) Teaching Geography 11-18-A Conceptual Approach.Maidenhead:Open University Press.Olofin, E.A (1987) The Kano Region .Bayero University, Kano.

[13] Stoddart,R \& Adams, W.M (2004) Fieldwork and Unity in Geography in Unity. In J. A Matthews and D. T Herbert (eds) Unifying geography: Common Heritage, Shared Future pp 46-61 Routledge, London

[14] Young, M (2008) Bringing Knowledge Back In: from social constructivism to social realism in the sociology of education, London: Routledge, p.22

[15] Young,M (2010) The future of education in a knowledge society: the radical case for a subject- based curriculum, Journal for the Pacific Circle Consortium for Education, 22, 1, pp 21-32 